\title{
Preliminary Survey for Uranium in Cretaceous Sandstones of Bonako-Sole Areas, Ngondo Complex, Southwestern Cameroon
}

\author{
Juliana Amboh Tifang ${ }^{1, *}$, Cheo Emmanuel Suh ${ }^{2}$, Ekah Nzume Ndimeh ${ }^{3}$, Ze Achille Desire ${ }^{1}$, \\ Mero Yannah ${ }^{1}$ \\ ${ }^{1}$ Institute of Geological and Mining Research, Yaounde, Cameroon \\ ${ }^{2}$ Department of Geology, University of Buea, Buea, Cameroon \\ ${ }^{3}$ Department of Geology, University of Yaounde 1, Yaounde, Cameroon
}

Email address:

Tjuliana10@yahoo.com (J. A. Tifang)

*Corresponding author

\section{To cite this article:}

Juliana Amboh Tifang, Cheo Emmanuel Suh, Ekah Nzume Ndimeh, Ze Achille Desire, Mero Yannah. Preliminary Survey for Uranium in Cretaceous Sandstones of Bonako-Sole Areas, Ngondo Complex, Southwestern Cameroon. Earth Sciences. Vol. 6, No. 1, 2017 , pp. 1-9. doi: $10.11648 /$ j.earth.20170601.11

Received: January 3, 2017; Accepted: January 18, 2017; Published: February 27, 2017

\begin{abstract}
Unconformity-type uranium deposits are characterized by mineralization developed along the contact between younger sandstone cover and underlying crystalline basement rocks. Twenty-five sandstone samples were collected at the Ngondo Complex of southwestern Cameroon along the unconformity contact from Bonako through Nyanga to Sole. Petrographic studies on thin sections revealed the presence of sub-rounded to angular quartz grains ( $80 \%$ grains) and ferruginous cement ( $20 \%$ cement). Some quartz grains also showed evidence of deformation. Radioelement concentrations for $\mathrm{U}, \mathrm{Th}$ and $\mathrm{K}$ were determined by gamma-ray spectrometry. The samples showed the various element concentration ranges; 0.03.3ppm U, 5.5-11.1ppm Th and $0.1-1.3 \% \mathrm{~K}$. Variations in the $\mathrm{U}$, Th and $\mathrm{K}$ concentration in the sandstone is related to the bedrock geology. The sandstones were also analysed for 21 associated elements using an X-ray fluorescence analyzer. Most of the samples showed moderate concentrations of $\mathrm{CaO}, \mathrm{Fe}_{2} \mathrm{O}_{3}, \mathrm{MgO}, \mathrm{TiO}_{2}, \mathrm{~K}_{2} \mathrm{O}, \mathrm{Zr}, \mathrm{Sr}, \mathrm{Nb}, \mathrm{Cr}$ and $\mathrm{V}$. Matrix of Pearson's correlation shows positive correlation between the following; U/Zn; U/Sc, V, Cr; U/Ti; $\mathrm{Zn} / \mathrm{Nb}, \mathrm{Ba}, \mathrm{TiO}_{2} ; \mathrm{Zn} / \mathrm{Zr}, \mathrm{V} / \mathrm{Zn}, \mathrm{Rb}, \mathrm{Cr}$, $\mathrm{Ba}$. These reflect the geology of the study area and also suggest the presence of heavy mineral phases like zircon, monazite, rutile.
\end{abstract}

Keywords: Unconformity-type, Uranium, Ngondo Complex, Cameroon

\section{Introduction}

Unconformity-type uranium deposits are usually found to occur as massive pods, veins or disseminations of uraninite found along major unconformities that separate Paleoproterozoic metamorphic basement from overlying younger siliciclastic formations [18]. The purpose of this study was to investigate an area in the locality of Penja, Douala in the Littoral Region, Cameroon. This research effort focused on geological units of the Neoproterozoic age which were mapped, sampled and analyzed both for radiometric elements as well as other associated geochemical elements.

Granitic rocks are known to have higher uranium content as compared to other rock types [7]. Leaching of these rocks by hydrothermal solutions could lead to the formation of secondary uranium [42]. Secondary uranium as well could also be formed as a result of oxidation of primary uranium minerals. Uranium deposits worldwide have been grouped into 15 major categories based on their geologic setting [35, $37,50,18]$. Some of these deposits which have been explored include: unconformity-type uranium deposit in the Athabasca Basin of Canada [46, 2, 1], the sandstone-type uranium deposit in the Karoo Basin in South Africa [24], vein-type hydrothermal uranium deposits in South China 
[15], quartz-pebble conglomerate uranium deposits [17], surficial uranium deposits [16], intrusive uranium deposits, volcanic uranium deposits, hematite breccia complex deposits, metamorphic deposits, uranium in black shales, uranium in phosphorites, and uranium in albitites.

Unconformity uranium deposits are one of the most sought after uranium deposits due to their unique high grades (mining grades range from 0.5 to $>24 \%$ U3O8) [18]. An example includes the Palaeoproterozoic unconformity-type uranium deposits in the Athabasca basin, Canada which is known to produce about one-third of the global uranium [21, 22]. These deposits usually occur as veins or massive pods or scattered either in the sandstone of the Athabasca Formation overlying the basement rocks or in the basement rocks themselves $[2,19,1]$.

Uranium has two major isotopes; ${ }^{235} \mathrm{U}$ and ${ }^{238} \mathrm{U}$ which usually occur in the ratio of 1:138 [25]. It also exist in variable valence states in nature which include: $\mathrm{U}^{4+}$ (tetravalent), $\mathrm{U}^{6+}$ (hexavelent) and $\mathrm{U}(\mathrm{OH})^{+3}$ (trivalent). These valences are very significant as they greatly control the mobilization, transportation, and deposition of uranium in its geological environment [49]. Thus $\mathrm{U}^{6+}$ is highly mobile under oxidizing conditions while $\mathrm{U}^{4+}$ is stable under reducing conditions [23]. The precipitation of $U$ in most deposits is related to a decrease of $\mathrm{O}_{2}$ which usually comes about as a result of the interaction of oxidized U-bearing fluids with carbonaceous matter under various states [48]. Some other potential reductants include; $\mathrm{H}_{2} \mathrm{~S}$, magnetite, ilmenite, and sulfides [18].

Two sub-types of unconformity related deposits which have been studied include [14, 41, 47]:

a) Fracture controlled sub-type which is usually hosted by basement rocks and typically occurs along shear zones, fractures or breccias which extend deep into the basement (about 400m).

b) Clay bounded sub-type which usually occurs as a massive pod (e.g pipe, cigar shapes) along the unconformity or in the overlying sediments with uranium grade decreasing from center outwards [18].

\section{Location and Geology of Study Area}

The area of interest (Figure 1) is situated in the southwestern part of Cameroon. It is centered in the Ngondo Complex along a NE strike-slip shear zone found in the southwestern part of the Neoproterozoic fold belt of Cameroon [45]. The study area lies along an unconformity interface between the Douala Basin and the Ngondo complex, with granitic rocks occurring at the north and sandstones to the south of the contact interface (Figure 1). Boneko, Njanga and Sole region forms part of the coastal lowlands, precisely the Douala Basin and extends towards the western highlands [27]. The area is low lying though some areas like Njanga and Sole have gently sloping hills. It is characterized by granites and gneiss of the Precambrian Era to the North and Cretaceous sediments to the South.

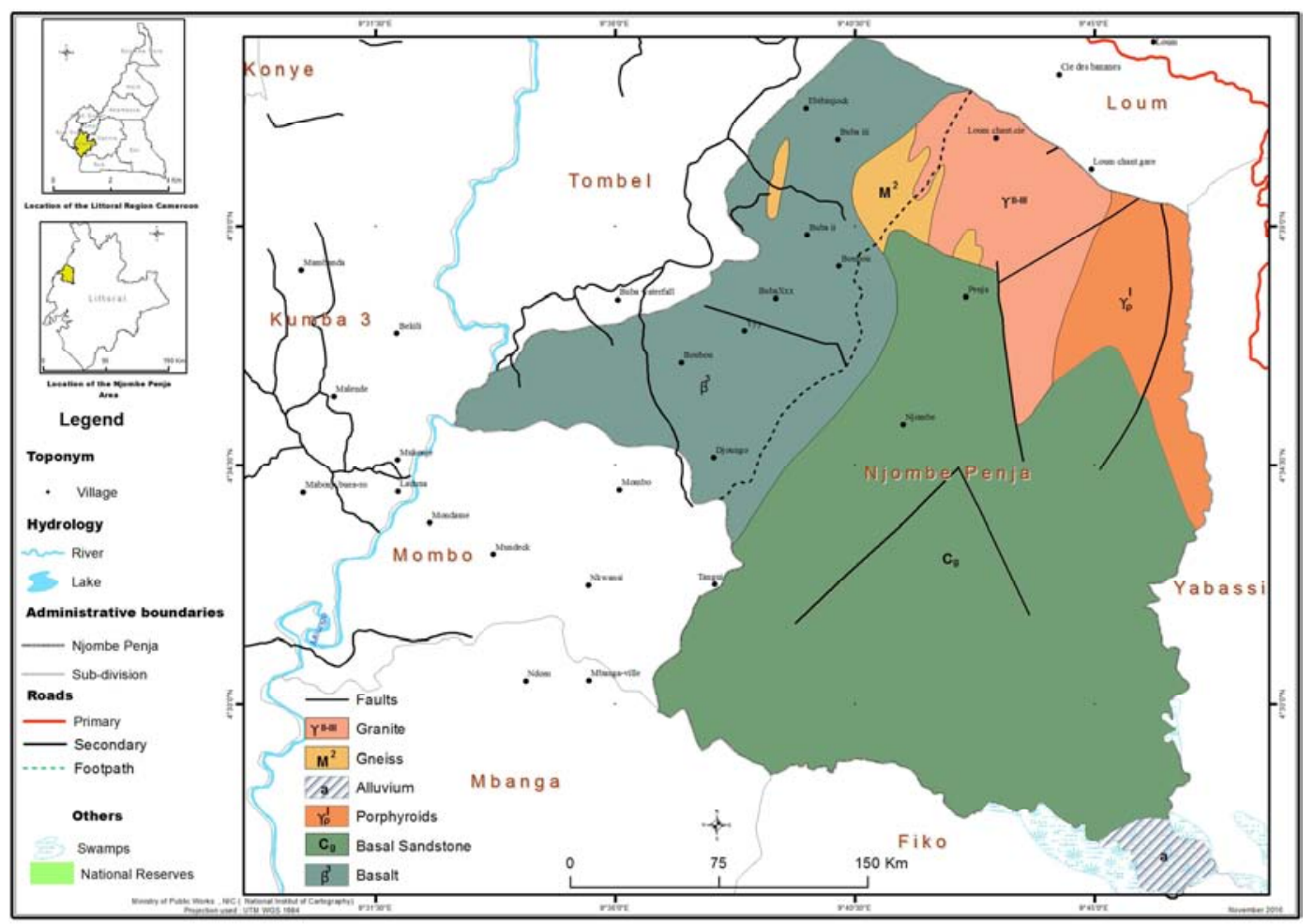

Figure 1. Geology map of the Bonako-Sole area.

The drainage system in the area follows a dendritic pattern (Figure 2). The area is well drained with the main river being River Mbede at Sole. The river has an irregular regime such that its volume decreases during the dry season and also increases greatly during the rainy season [27]. 


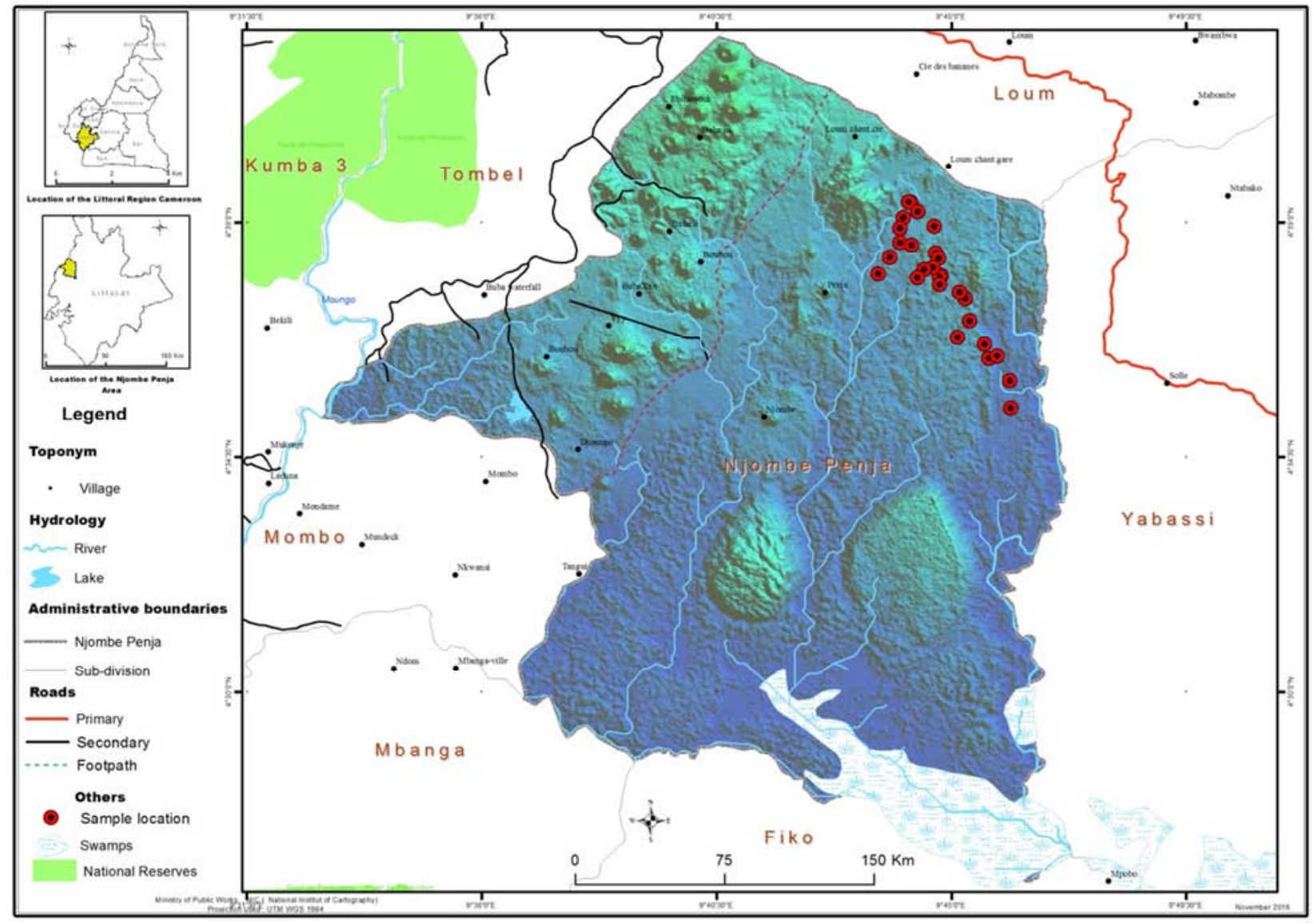

Figure 2. Sample location map of the study area

This region falls within the dense equatorial forest belt of Cameroon more precisely in the mangrove forest and is characterized by the "Cameroon type" of climate [27] typically consisting two seasons, one wet season of about eight months during which time rains are abundant throughout, and a dry season.

The Neoproterozoic fold belt of Cameroon (NFBC) is part of the Central African orogenic belt which is a major Neoproterozoic Orogen that is linked to the Trans-Saharan Belt of western Africa [20]. Studies carried out suggest that the belt came about as a result of a NW-SE collision between the West African and Congo cratons [31, 28]. This fold belt is partly covered by basalts and trachytes of Tertiary to Recent age and consist of three domains [31, 32, 29, 30, 33, 34]. The domain related to this study area is the southern domain comprising Neoproterozoic metasedimentary units, such as the Yaoundé, Mbalmayo and Ntui-Betamba series. This Neoproterozoic fold belt (the Ngondo Complex) is composed of a Palaeoproterozoic migmatitic-gneiss basement, MesoNeoproterozoic deformed and metamorphosed volcanosedimentary sequences and Pan-African granitoids which intruded the former two units [9]. The Ngondo complex is a high $\mathrm{K}$, calc-alkaline to sub-alkaline pluton made up of three successively emplaced intrusions; mafic to felsic intrusive rocks (MFR), fine-grained granites (FGG) and coarsegrained granites (CGG) [45]. The southern part of the complex is overlain by Cretaceous sandstone [45] of the Douala basin. It is a sedimentary basin of Cretaceous to Tertiary age and has a total surface area of about $7000 \mathrm{~km}^{2}$ and a maximum width of $60 \mathrm{~km}[10,40,44]$. The origin and structure of the Douala basin is associated with the opening of the South Atlantic Ocean, genetically related to the breakup of Gondwanaland. The Stratigraphy of the basin consists of the Cretaceous Mungo River Formation, overlain by the Tertiary Mpundu Formation. The Mungo River Formation consists dominantly of sandstone with a few intercalations of limestone and shale. The Mpundu Formation consists of poorly consolidated grits and sandstones that occasionally display bedding [3].

\section{Methodology}

A total of 25 sandstone samples weighing about $1 \mathrm{~kg}$ each were collected close to the unconformity starting from Bonako, through Njanga to Sole. Representative sandstone samples were subsequently thin-sectioned at the Laboratoire de Traitément des Minerais (LTM) de Nkolbisson in Yaoundé and later observed under a petrographic microscope to determine the mineralogy and texture of the sandstones.

A radiometric survey was also carried out using a portable gamma ray spectrometer (GR-135GPlus), which consists of a detector and the instrument body (Plate. 2.1). The detector is 
composed of $\mathrm{NaI}(\mathrm{Tl})$ crystal and a Geiger-Muller tube. It was used to detect the presence of uranium and also to get the concentrations of $\mathrm{U}(\mathrm{ppm}), \mathrm{Th}(\mathrm{ppm})$ and $\mathrm{K}(\%)$. At each outcrop, the GR spectrometer was placed at a given position in direct contact with the rock and allowed to read the concentrations of $\mathrm{U}$, Th and $\mathrm{K}$.

The Thermo Scientific Niton XL3t handheld X-ray fluorescence analyzer was used to analyze for the concentration of various elements in the samples. Before use, the Niton XL3t XRF analyzer is switched on and allowed to heat for five minutes. During use, the sensor is focused on the sample. The handheld XRF analyzer detects elements present and shows their concentration on the integrated tilting color touch-screen. The analyzer takes about 30 seconds to determine elements present in each sample.

\section{Results and Discussion}

The Sandstones as observed on the field are loose and some indurated, ranging from fine-grained to coarse-grained sandstones. They are poorly sorted and contain about $25 \%$ clay. Sandstone categories present range from clayey sandstone, silty sandstone, ferruginous sandstone to conglomeritic sandstone, with colors including yellowishbrown, reddish-brown, brown and dark-brown. The main minerals recognized in these sandstones are quartz $(75-80 \%)$ and clay. Some highly indurated sandstones were also observed and these are fine- to coarse-grained with a reddishbrown cement holding the grains together and also giving the rock an overall reddish-brown coloration.

Under the microscope, the sandstone is medium- to coarsegrained and the grains range in size from $2 \mathrm{~mm}-4 \mathrm{~mm}$. The quartz grains are isolated and have serrated and irregular edges. Most grains are sub-rounded to angular. Some grains have micro fractures, deformation lamellae and subgrains which show evidence of deformation and re-crystallization. Most of these fractures are open while some are filled with secondary cement. The sandstones are largely poorly sorted and contain about $80 \%$ mineral grains, set in $\sim 20 \%$ iron-rich cement or matrix. The iron-bearing cement occurs as grain coatings and pore fillings and is the dominant cementing agent. The main mineral present is quartz and the rock is almost devoid of feldspars $(<2 \%)$.

\subsection{Radiometry}

The concentration of $U$ in the sandstone samples ranged from $0.3 \mathrm{ppm}$ to $3.3 \mathrm{pp}$ with an average of $1.6 \pm 0.8(\mathrm{ppm})$, while Th concentration ranges from $6 \mathrm{ppm}$ to $11.1 \mathrm{ppm}$ and has an average of $8.0 \pm 1.5(\mathrm{ppm})$, and $\mathrm{K}$ has an average of $0.9 \pm 0.4(\%)$. Highest concentrations of $U$ were found at locations $\mathrm{BO} / 08 \mathrm{SS}, \mathrm{BO} / 08 \mathrm{bSS}, \mathrm{BO} / 22 \mathrm{SS}$.

The matrix of Pearson's Correlation coefficient (Table 1) which measures the strength of a linear relationship between any two variables on a scale of -1 (perfect inverse relation) through 0 (no relation) to +1 (perfect sympathetic relation) was used to analyze the relationships which exist between the various elements. Although uranium does not correlate with any particular element, correlation coefficients of $\mathrm{U}$ with $\mathrm{Cr}$, $\mathrm{Zn}, \mathrm{Rb}, \mathrm{Ba}$ and $\mathrm{V}$ represent the highest values ranging between 0.37 and 0.49 . This indicates that the geochemical environment responsible for this should be that with a large association with lithophile elements which occur in minerals like Monazite and Zircon.

Table 1. Matrix of Pearson's correlation for major and trace elements in the sandstones from the Bonako, Nyanga and Sole areas, southwestern Cameroon.

\begin{tabular}{|c|c|c|c|c|c|c|c|c|c|c|c|c|c|c|c|c|c|}
\hline & $\mathrm{CaO}$ & $\mathrm{Fe}_{2} \mathrm{O}_{3}$ & $\mathrm{~K}_{2} \mathrm{O}$ & MnO & $\mathrm{TiO}_{2}$ & $\mathbf{B i}$ & $\mathbf{B a}$ & $\mathbf{N b}$ & $\mathbf{Z r}$ & $\mathrm{Sr}$ & $\mathbf{R b}$ & $\mathbf{Z n}$ & $\mathrm{Cr}$ & V & $\mathbf{U}$ & Th & $\mathbf{K}$ \\
\hline $\mathrm{CaO}$ & 1 & & & & & & & & & & & & & & & & \\
\hline $\mathrm{Fe}_{2} \mathrm{O}_{3}$ & 0.37 & 1.00 & & & & & & & & & & & & & & & \\
\hline $\mathrm{K}_{2} \mathrm{O}$ & 0.04 & -0.18 & 1.00 & & & & & & & & & & & & & & \\
\hline $\mathrm{MnO}$ & 0.51 & 0.61 & 0.32 & 1.00 & & & & & & & & & & & & & \\
\hline $\mathrm{TiO}_{2}$ & 0.11 & 0.36 & -0.25 & 0.27 & 1.00 & & & & & & & & & & & & \\
\hline $\mathrm{Bi}$ & 0.52 & 0.05 & 0.05 & -0.37 & -0.19 & 1.00 & & & & & & & & & & & \\
\hline $\mathrm{Ba}$ & 0.39 & 0.62 & 0.60 & 1.00 & 0.74 & 0.82 & 1.00 & & & & & & & & & & \\
\hline $\mathrm{Zr}$ & 0.15 & 0.22 & 0.28 & -0.03 & 0.69 & 0.03 & 0.81 & 0.58 & 1.00 & & & & & & & & \\
\hline $\mathrm{Sr}$ & -0.16 & -0.39 & 0.25 & -0.20 & -0.43 & 0.36 & -0.72 & -0.48 & -0.33 & 1.00 & & & & & & & \\
\hline $\mathrm{Rb}$ & 0.08 & -0.11 & 0.79 & -0.05 & 0.19 & 0.47 & 0.16 & -0.14 & 0.48 & -0.09 & 1.00 & & & & & & \\
\hline $\mathrm{Zn}$ & 0.51 & 0.21 & -0.17 & 0.61 & 0.76 & -0.14 & 0.92 & 0.81 & 0.67 & -0.46 & 0.05 & 1.00 & & & & & \\
\hline $\mathrm{Cr}$ & 0.42 & 0.15 & -0.12 & -0.08 & 0.13 & 0.51 & -0.06 & 0.05 & -0.25 & -0.03 & 0.29 & 0.13 & 1.00 & & & & \\
\hline V & 0.22 & 0.05 & 0.24 & 0.45 & 0.46 & 0.65 & 0.77 & 0.23 & 0.29 & 0.12 & 0.47 & 0.48 & 0.51 & 1.00 & & & \\
\hline $\mathrm{U}$ & 0.26 & -0.31 & 0.08 & 0.24 & 0.23 & 0.49 & 0.47 & 0.08 & 0.15 & 0.26 & 0.03 & 0.45 & 0.39 & 0.37 & 1.00 & & \\
\hline
\end{tabular}

The sandstones in the study area show maximum uranium concentration of $3.3 \mathrm{ppm}$ which is similar to the $U$ concentration of a typical granite; 3.2ppm [12]. The U present in the sandstones could possibly have its source in the basement (granites), where it must have been leached by basement fluids and then transported to the sandstones where it was deposited $[8,13]$. This can be explained by the fact that uranium has a tendency to form complexes with a good number of naturally occurring anions. These complexes facilitate the solubility and mobility of $U$ in the secondary environment [24]. For uraninite to be precipitated in the sandstone in this context, basement fluids must be both spatially and temporally associated to promote uraninite precipitation in a sandstone hosted context $[14,11]$. 
Importantly, the timing of the alteration events should be such as not to impede the fluid circulation patterns required to form a deposit. This condition was not met in the area of study. Also, the structural situation of this area, such as the absence of major faults did not favor the penetration of basin fluids into the potential physical trap zone at the intersection of these faults with the unconformity. Also the natural radioactive elements $\mathrm{U}$, Th and $\mathrm{K}$ are lithophile elements. They are strongly partitioned in the continental crust and their average content varies as a function of rock type. Acidic rocks usually contain more $\mathrm{K}$, Th and $\mathrm{U}$ than mafic rocks and in sediments; these elements are likely to be more concentrated in argillaceous deposits than in sandstones and limestones [25]. This possibly explains the relatively low concentrations of these elements in the sandstone samples.

With respect to the linear correlation coefficients for the radioactive elements, the very weak negative correlation which exists between $U$ and the elements $T h, K$ suggest that the distribution of these elements is partly controlled by the lithology of the area (Figures 3, 4, 5). The $U$ was most likely leached from detrital zircon, monazite and apatite and $\mathrm{K}$ from altered feldspar and lithic clasts [11].

\subsection{Element Association}

In terms of whole rock geochemistry, all the sandstone samples collected from the Bonako, Nyanga and Sole areas are composed of the following elements: $\mathrm{CaO}, \mathrm{Fe}_{2} \mathrm{O}_{3}, \mathrm{MgO}$, $\mathrm{Zr}, \mathrm{Sr}, \mathrm{Cr}, \mathrm{K}_{2} \mathrm{O}, \mathrm{V}, \mathrm{TiO}_{2}$, Nb. The Ngondo Complex is a high $\mathrm{K}$, calc-alkaline to sub-alkaline pluton emplaced during the Neoproterozoic D2 Pan-African event in Cameroon [45].
This supports the presence of $\mathrm{K}_{2} \mathrm{O}$ and $\mathrm{CaO}$ in the sandstones, given that they must have been moved to the secondary environment through leaching and weathering of the basement rocks which are predominantly granites and other mafic rocks. With respect to the linear correlation (Table 1) for the major and trace elements, the positive correlation between $\mathrm{TiO}_{2}$ and the elements $\mathrm{Nb}, \mathrm{Zn}, \mathrm{Zr}, \mathrm{Ba}, \mathrm{V}$ in the secondary environment shows that these elements come from very resistant minerals such as zircon, rutile and monazite. Also, the enrichment of $\mathrm{Zr}, \mathrm{U}$, Th, $\mathrm{Ti}$ and $\mathrm{Nb}$ in these sediments which are high field strength elements indicates their source rock could be granitic [4]. The strong positive correlation of $\mathrm{Zn}$ with several other elements is because $\mathrm{Zn}$ is highly mobile and is also naturally abundant in the crust and in sedimentary rocks [26].

\subsection{Element Distribution}

Uranium can be introduced into the secondary environment through the leaching of uranium from granites and/or other uranium-rich rocks. The circulation of hydrothermal fluids can also result in secondary uranium deposits marked by the oxidation of primary uranium minerals [13, 8, 38]. A number of secondary uranium occurrences worldwide is associated with unconformities $[14,11,46,39,2,5,6]$ or sandstones [43]. This study examines a zone of unconformity between a granitic basement and overlying sandstones in SW Cameroon. In this study highest uranium concentration was at $3.3 \mathrm{ppm}$. Figures 3,4 , and 5 below show the concentrations and distribution of all three radioelements as observed in the field.

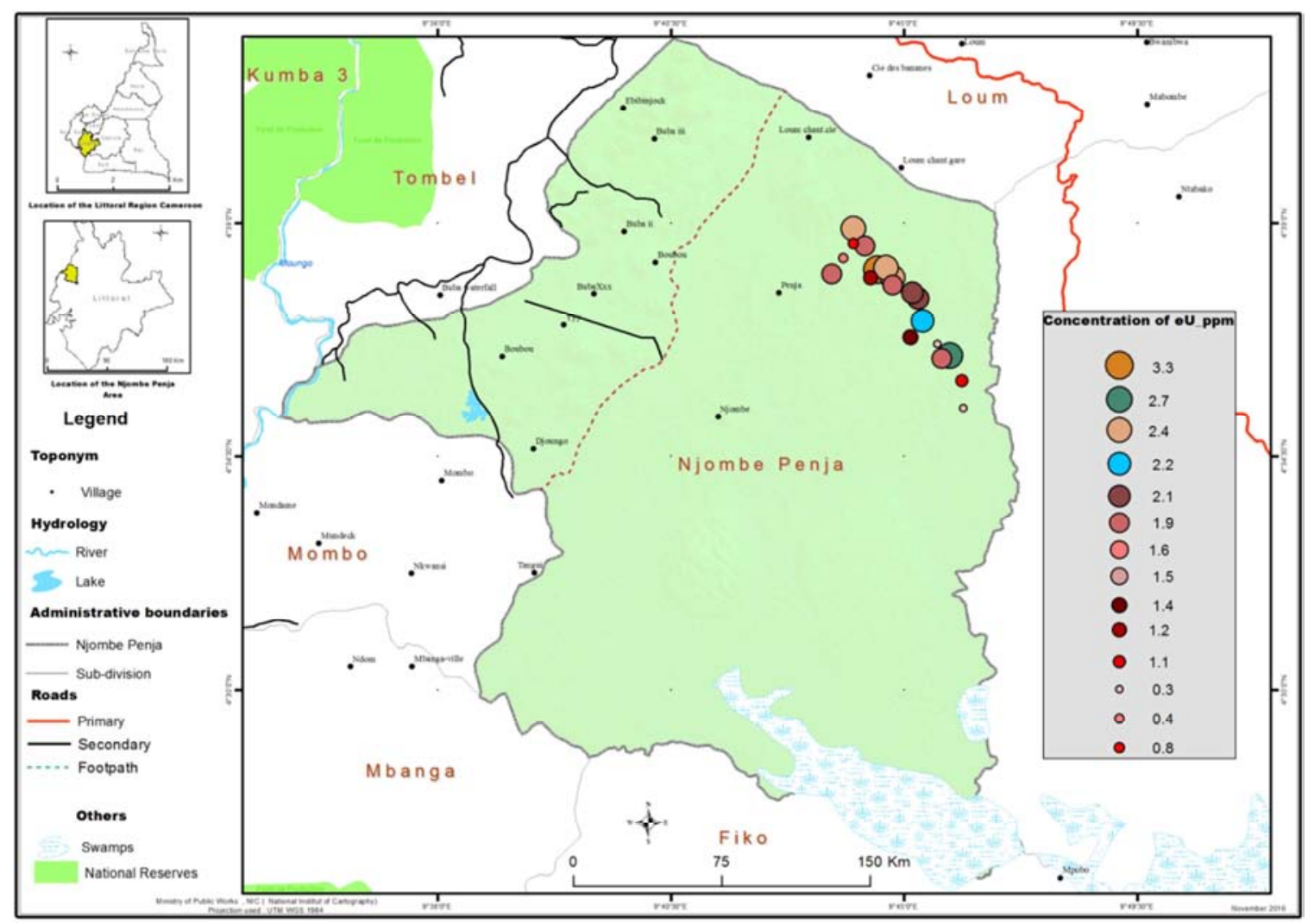

Figure 3. Distribution of uranium concentrations in the sandstones within the Bonako, Nyanga and Sole areas, southwestern Cameroon. 


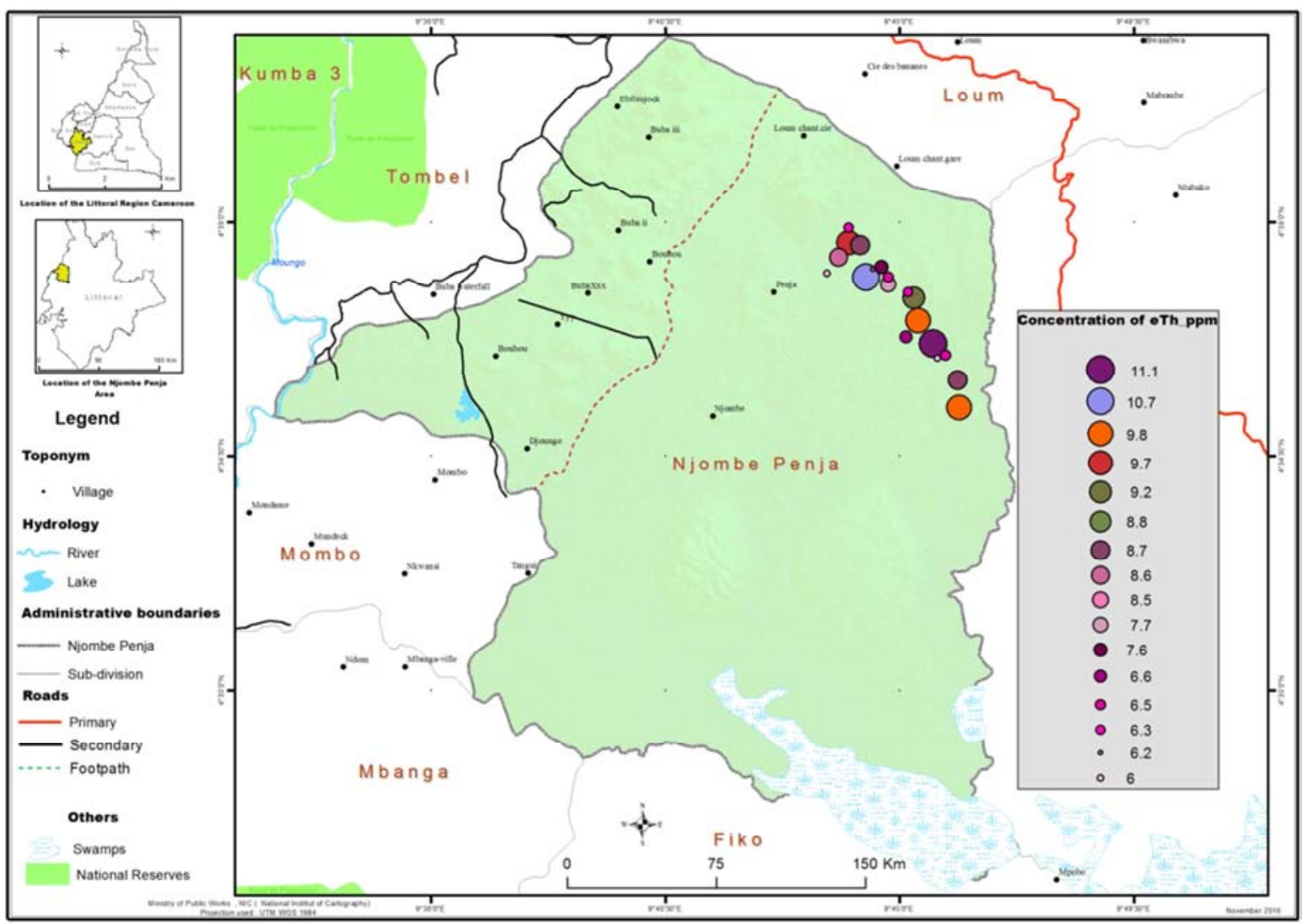

Figure 4. Distribution of thorium concentrations in the sandstones within the Bonako, Nyanga and Sole areas, southwestern Cameroon.

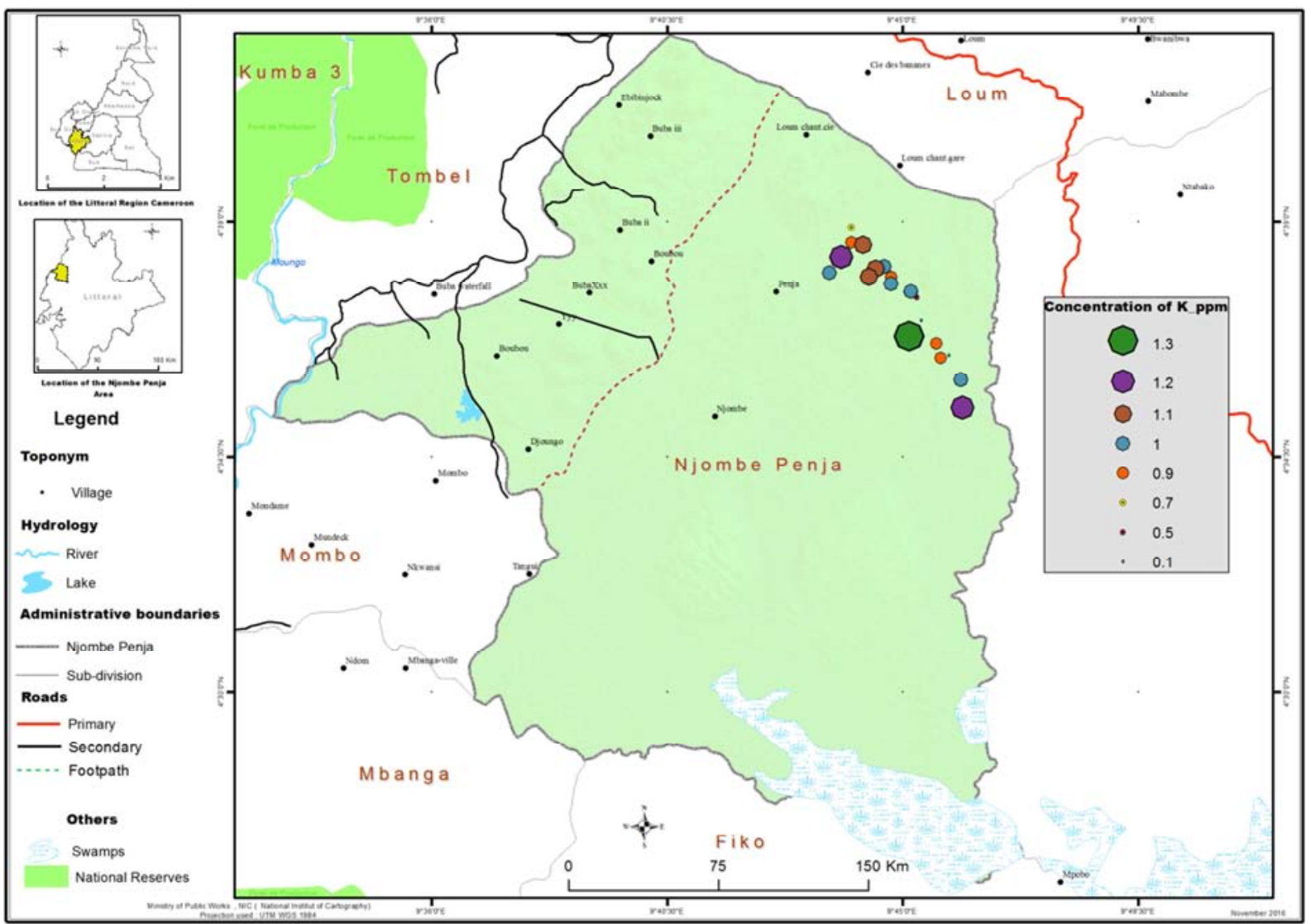

Figure 5. Distribution of potassium concentrations in the sandstones within the Bonako, Nyanga and Sole areas, southwestern Cameroon. 
From this study, uranium indices have been identified however, the mineralization of potential economic significance has not been found. Accepting that the granitic rocks of the Ngondo Complex are older than the surrounding sediments, the uranium present in the sandstones maybe related to the granites. The main geochemical pathways envisaged for the deposition of the $\mathrm{U}$ can, therefore, be summarized as follows:

i. Uranium is leached from the granitic rocks or from detrital material within the sandstone by fluids, possibly heated, probably by simple diagenetic compaction.

ii. Groundwater moving along the brittle openings transported the $\mathrm{U}$ in the form of uranyl complexes in association with $\mathrm{Fe}, \mathrm{Ba}, \mathrm{Cr}$, V. Such uranyl complexes often bear carbonates, but these uranyl complexes in the study area are not carbonate-based.

iii. Interaction of this groundwater with organic matter and possibly sulphides, led to freed uranyl cation-bearing solutions to form insoluble secondary uranium.

\section{Conclusion}

The sandstones in this study area are generally medium to coarse grained and are constitute about $25 \%$ clay and $75-85 \%$ quartz. They are generally yellowish brown to reddish brown in color owing to the ferruginous cement present. Most of the quartz grains are subrounded to angular with some having micro fractures (some fractures are filled) and deformation lamellae indicating evidence of deformation and recrystallization. Uranium concentrations in the sandstones ranges from $0.3-3.3 \mathrm{ppm}$ with an average of $1.6 \pm 0.8 \mathrm{ppm}$. Correlation coefficients of $\mathrm{U}$ with $\mathrm{Cr}, \mathrm{Zn}, \mathrm{Rb}, \mathrm{Ba}$ and $\mathrm{V}$ represent the highest values ranging between 0.37 and 0.49 . This indicates that the geochemical environment is largely associated with lithophile elements which occur in minerals like Monazite and Zircon. The Uranium present in the sandstones is thought to have its source from the basement granites where it should have been leached by basement fluids and then transported and deposited in the overlying sandstone cover. The sandstones were also found to be rich in the following major and minor elements: $\mathrm{CaO}, \mathrm{Fe}_{2} \mathrm{O}_{3}, \mathrm{MgO}$, $\mathrm{Zr}, \mathrm{Sr}, \mathrm{Cr}, \mathrm{K}_{2} \mathrm{O}, \mathrm{V}, \mathrm{TiO}_{2}, \mathrm{Nb}$, explained by the fact that the Ngondo Complex is a high $\mathrm{K}$, Calc-alkaline to sub-alkaline pluton. From this study, uranium indices have been identified, however mineralization of economic value was not found.

\section{References}

[1] Alexandre, P., Kyser, K., and Jiricka, D. (2009): Critical geochemical and mineralogical factors for the formation of unconformity-related uranium deposits: Comparison between barren and mineralized systems in the Athabasca Basin, Canada Economic Geology, 104, 431-435.

[2] Alexandre, P., Kyser, K., Polito, P., and Thomas, D. (2005): Alteration mineralogy and stable isotope geochemistry of
Paleoproterozoic basement-hosted unconformity-type uranium deposits in the Athabasca Basin, Canada. Economic Geology, $100,1547-1563$.

[3] Asaah, V. A., Abimbola, A. F. and Suh, C. E. (2006): Heavy metal concentrations and distribution in surface soils of the Bassa industrial zone 1, Douala, Cameroon. The Arabian Journal for Science and Engineering, 31 (2A), 147-158.

[4] Chandrajiath, R., Dissanayake, C. B., Tobscall, H. J. (2001): Enrichment of high field strength elements in stream sediments of a granulite terrain in Sri Lanka- evidence for a mineralized belt. Chemical Geology, 175, 259-271.

[5] Cloutier, J., Kyser, K., Olivo, G. R., Alexandre, P. (2010): Contrasting patterns of alteration at the Wheeler river area, Athabasca basin, Saskatchewan, Canada: Insights into the apparently uranium-barren zone $\mathrm{K}$ alteration system. Journal of Economic Geology, 105, 303-324.

[6] Cloutier, J., Kyser, K., Olivo, G. R., Alexandre, P. and Halaburda, J. (2009): The millennium uranium deposit, Athabasca basin, Saskatchewan, Canada: An Atypical basement-hosted unconformity-related uranium deposit. Journal of Economic Geology, 104, 815-840.

[7] Dawood, Y. H and Abdel-Nabel, H. H. (2001): Mineralogy and genesis of secondary uranium deposits, Um Ara area, south eastern desert, Egypt. Journal of African Earth Sciences, $32(2), 317-323$.

[8] Derome, D., Cuney, M., Cathelineau, M., Fabre, C., Dubessy, J., Bruneton, P. and Hubert, A. (2003): A detailed fluid inclusion studies in silicified breccias from the Kombolgie sandstones, Northern Territory, Australia. Influences for the genesis of middle-Proterozoic unconformity-type uranium deposit. Journal of Geochemical Exploration, 80, 259-275.

[9] Djouka-Fonkwe, M. L., Schulz, B., Schussler, U., Tchouankoue, J. P. and Nzolang, C. (2008): Geochemistry of the Pan-African I and S-type granitoids in western Cameroon. Journal of African Earth Siences, 50, 148-167.

[10] Dumort, J. P. (1968): Notice explicative sur la feuille de Douala-Ouest. Direction Mines et de la Geologie du Cameroon, Yaounde, 69, 56p.

[11] Fayek, M. and Kyser, k. (1997): Characterisation of multiple fluid-flow events and rare-earth element mobility associated with formation of unconformity uranium deposits in the Athabasca Basin, Saskatchewan. Canadian Mineralogist, 35, 627- 658 .

[12] Flanagan, F. J., Smith, W. L. and Sherwood, A. M. (1960): A comparison of two estimates of the thorium content of the Conway granite, New Hampshire. U. S. Geological Survey professional paper, 400-B, 168-169.

[13] Hecht, L. and Cuney, M. (2000): Hydrothermal alteration of monazite in the Precambrian crystalline basement of the Athabasca Basin, Saskatchewan, Canada: Implications for the formation of unconformity-related uranium deposits. Mineraliun Deposita, 35, 791-795.

[14] Hoeve, J. and Quirt, D. (1984): Mineralization and host rock alteration in relation to clay mineral diagenesis and evolution of the Middle-Proterozoic Athabasca Basin, northern Saskatchewan, Canada, Saskatchewan Research Council, SRC Technical Report, 187. 
[15] Hu, R. Z., Bi, X. W., Zhou, M. F., Peng, J. T., Su, W. C., Liu, S., and Qi, H. W. (2008): Uranium metallogenesis in South China and its relationship to crustal extension during the Cretaceous to Tertiary. Journal of Economic Geology, 103, 583-598.

[16] International Atomic Energy Agency, (1984): Geological environments of sandstone-type uranium deposits. IAEA, Vienna, TECDOC-328.

[17] International Atomic Energy Agency, (1987): Uranium deposits in Proterozoic- quartz-pebble conglomerates. IAEA, Vienna, TECDOC-427.

[18] International Atomic Energy Agency, (2009): World distribution of uranium deposits (UDEPO) with uranium deposit classification, IAEA, Vienna, TECDOC - 1621 .

[19] Jefferson, C. W., Thomas, D. J., Gandhi, S. S., Ramaekers, P., Delaney, G., Brisbin, D., Cutts, C., Portella, P. and Olson, R. A. (2007): Unconformity associated uranium deposits of the Athabasca Basin, Saskatchewan and Alberta. Saskatchewan Geologic Society Special publication, 18.

[20] Kouankap Nono, G. D., Nzenti, J. P., Suh, C. E. and Ganno, S. (2010): Geochemistry of ferriferous, high K calc-alkaline granitoids from the Banefo-Mvoutsaha massif (NE Bafoussam), central domain of the Pan-African fold belt, Cameroon. Open Geology Journal, 4, 15-28.

[21] Krasenberg, H. J. (2004): The newest gold, Uranium, European gold center, Oct 10, 1-3.

[22] Kyser, K. and Cuney, M. (2008): Unconformity-related uranium deposits. Recent and not-so-recent developments in uranium deposits and implications for exploration. Mineralogical association of Canada Short Course, 39, 161219.

[23] Langmuir, D. (1978): Uranium solution-mineral equilibria at low temperatures with applications to sedimentary ore deposits. Geochim Cosmochim Acta, 42, 547-569.

[24] Le Roux, J. P. (1993): Genesis of stratiform U-Mo deposits in the Karoo Basin of South Africa. Ore Geology Reviews, 7, 485-509.

[25] Lima, A., Albanese, S., Cicchella, D. (2005): Geochemical baselines for the radioelements $\mathrm{K}, \mathrm{U}$ and $\mathrm{Th}$ in the Campania region, Italy: a comparism of stream sediment geochemistry and gamma-ray surveys. Applied Geochemistry, 20, 611- 625.

[26] Naseem, S., Sheikh, S. A., Qadeeruddin, M., Shrink, K. (2002): Geochemical stream sediment survey in Winder valley, Balochistan, Pakistan. Journal of Geochemical Exploration, 76, 1-12.

[27] Neba, A. (1999): Modern geography of the Republic of Cameroon. Third edition, 266p.

[28] Nédélec, A., Macaudiere, J., Nzenti, J. P. and Barbey, P. (1986): Evolution struturale et metamorphique de schistes de Mbalmayo (Cameroun). Implication sur la structure de la zone mobile panafricain d'Afrique Centrale au contact du craton du Congo. C. R. Acad. Science, 303, 75-80.

[29] Ngnotué, T., Nzenti, J. P., Barbey, P. and Tchoua, F. M. (2000): The Ntui Bétamba high-grade gneisses: a northward extension of the Pan-African Yaoundé gneisses in Cameroon. Jouranal of African Earth Sciences. 31, 369-381.
[30] Njiosseu, E. L. T., Nzenti, J. P., Njanko, T., Kapajika, B. and Nédelec, A. (2005): "New U-Pd zircon ages from Tonga (Cameroon): Coexisting Eburnean- Transamazonian (2.1 Ga) and Pan-African (0.6 Ga) imprints", C. R. Géoscience, 377, 551-562.

[31] Nzenti, J. P., Barbey, P., Jegouzo, P. and Moreau, C. (1984): Un nouvel example de ceinture granulitique dans une chaîne protérozoique de collision: les migmatites de Yaoundé au Cameroun. C. R. Acad. Science, 299 (17), 1197-1199.

[32] Nzenti, J. P., Barbey, P. and Tchoua, F. M. (1999): "Evolution crustale au Cameroun: élément pour un modèle géodynamique de l'orogenèse néoprotérozoïque", In: Vicat, J. P. and Bilong, P. Eds, Géologie et environnements au Cameroun. Collection GEOCAM: 397-407.

[33] Nzenti, J. P., Kapajika, B., Wörne, G. and Lubala, T. R. (2006): Synkinematic implacement of granitoids in a PanAfrican Shear zone in Central Cameroo. Journal of African Earth Sciences. 45, 74-86.

[34] Nzenti, J. P., Njiosseu Tanko, E. L. and Nzina Nchare, A. (2007): The metamorphic evolution of the Paleoproterozoic high grade Banyo gneisses (Adamawa, Cameroon, Central Africa). Cameroon Accademy Journal of Science, 7, 95-109.

[35] OECD and IAEA, 2006, Uranium, (2005): Resources, production and demand, Paris, France, Organisation for Economic Coperation and Development, 388p.

[36] OECD Nuclear Energy Agency, IAEA, Uranium 2007. (2008): Resources, Production and Demand, OECD, Paris.

[37] OECD Nuclear Energy Agency, IAEA, Uranium (2014): Resources, Production and Demand ("Red Book").

[38] Polito, P. A., Kyser, T. K., Stanley, C. (2009): The Proterozoic, albitite-hosted, Valhalla uranium deposit, Queensland, Australia: a description of the alteration assemblage associated with uranium mineralization in diamond drill hole V39. Minera Deposita, 44, 11-40.

[39] Quirt, D. H. (2003): Athabasca unconformity-type uranium deposits. One deposit type with many variations. Uranium Geochemistry 2003, International Conference, Nancy, France, April 13-16, Proceedings, 309-312.

[40] Regnoult, J. M. (1986): Synthese Geologique du Cameoun, Yaounde: Ministere des mines et de l'energie, Republic du Cameroun. 119p.

[41] Sibbald, T. I. I. (1985): Geology and genesis of the Athabasca basin uranium deposits; in summary of investigations. Saskatchwan Geologic Survey, Saskatchewan Energy and Mines, Miscellaneous report, 84, 133-156.

[42] Stuckless, J. S. and Ferreira, C. P. (1976): Labile uranium in granitic rocks. In Exploration of uranium ore deposits. Proceedings International Atomic Energy Agency, Vienna, 717-730.

[43] Suh, C. E., Dada, S. S. and Matheis, G. (2000): Host rock geology and geochemistry of the Zona uranium occurrence, Peta Gulf syncline (upper Benue trough), northeast Nigeria. Journal of African Earth Science, 31 (3/4), 619-632.

[44] Tamfu, S. and Batupe, M. (1995): Geologic setting, stratigraphy and hydrocarbon habitat of the Douala Basin, Cameroon. National Hydrocarbon Journal of Cameroon, 003, p. 6 . 
[45] Tangne-Kamga, G. (2003); Petrogenesis of the Neoproterozoic Ngondo plutonic Complex (Cameroon, West central Africa): a case of late ferro-potassic magmatism. Journal of African Earth Science, 36, 149-171.

[46] Thomas, D. J., Matthews, R. B., and Supuck, V. J. (1998): Athabasca Basin unconformity-type uranium deposits: A synopsis of the empirical model and review of exploration and production trends: Canadian Institute of Mining, Metallurgy and Petroleum meeting, Montreal, May 3-7, Proceedings, 1998.

[47] Thomas, D. J., Matthews, R. B., Sopuck, V. (2000): Athabasca Basin (Canada) unconformity-type uranium deposits: Exploration model, current mine developments and exploration directions, geology and ore deposits, the great basin and beyond. Proceedings of Geological Society of Nevada symposium, 1, 103-126.

[48] Thomas Riegler, Marie-France Beaufort, Thierry Allard, Anne-Catherine Pierson-Wickmann, Daniel Beaufort (2016). Nanoscale relationships between uranium and carbonaceous material in alteration halos around unconformity-related uranium deposits of the Kiggavik camp, Paleoproterozoic Thelon Basin, Nunavut, Canada. Ore Geology Reviews, Elsevier, 79, 382-391.

[49] Wolf, K. H. (1976): Handbook of strata-bound and stratiform ore deposits. Elsevier.

[50] World Nuclear Association (2015): Geology of Uranium deposits. 